\title{
ОСОБЛИВОСТІ РОЗВИТКУ ПРОМИСЛОВОСТІ УКРАЇНИ В СУЧАСНИХ УМОВАХ
}

\author{
Остапюк Б.Я., к.е.н., ст.викладач, \\ Груник I.C., к.т.н., доцент, \\ Легенький М.I., магістр, \\ Легенький Ю.І., магістр (УкрДУЗТ)
}

В статті вияснено, щзо промисловість для Украӥни це найважливіший системоутворюючий чинник начіональної економіки, який значною мірою визначає рівень розвитку кожної ї̈ галузі. Виявлено основних світових лідерів розвитку промисловості. Проаналізовано сучасний стан та розвиток вітчизняної промисловості. Виявлено, щзо проблеми промисловості мають загальнонаціональний масштаб. Для виходу із кризи необхідне формування і реалізація комплексної програми інноваційного розвитку промислових галузей і механізмів, щэо в свою чергу забезпечить динамічну модернізацію краӥни в цілому.

Ключові слова: промисловість, модернізація, продукція, деіндустріалізація економіки, розвиток.

\section{ОСОБЕННОСТИ РАЗВИТИЯ ПРОМЫШЛЕННОСТИ УКРАИНЫ В СОВРЕМЕННЫХ УСЛОВИЯХ}

\author{
Остапюк Б.Я., к.э.н., ст.преподаватель, \\ Груник И.С., к.т.н., доцент, \\ Легенький М.И., магистр, \\ Легенький Ю.И., магистр (УкрГУЖТ)
}

\begin{abstract}
В статье выяснено, что промышленность для Украины - это важнейшый системообразуюийя фактор начиональной экономики, в значительной мере определяет уровень развития каждой ее области. Выявлено основных мировых лидеров развития промышленности. Проанализировано современное состояние и развитие отечественной промышленности. Выявлено, что проблемы промышленности имеют общеначиональный масштаб. Для выхода из кризиса необходимо формирование и реализация комплексной программы инновационного развития промышленных отраслей и механизмов, в свою очередь обеспечит динамическую модернизацию страны в циелом.
\end{abstract}

Ключевые слова: промышленность, модернизация, продукция, деиндустриализация экономики, развитие.

(С) Остапюк Б.Я.,

Груник I.C.,

Легенький M.I.,

Легенький Ю.І.

Вісник економіки транспорту і промисловості № 62, 2018 


\title{
PECULIARITIES OF DEVELOPMENT OF INDUSTRY OF UKRAINE IN MODERN CONDITIONS
}

\author{
Ostapyuk B.Ya., Candidate of Economic Science, Senior Lecturer, \\ Grunk I.S., Candidate of Technical Science, assistant professor, \\ Legenky M.I., master's degree, \\ Lezhenky Yu.I., master's degree (USURT)
}

The article clarifies that industry for Ukraine is the most important system that creates the factor of the national economy, which largely determines the level of development of each of its branches. The main world leaders in the development of industry have been identified. The present state and development of the domestic industry are analyzed. It is revealed that the problems of industry have a nationwide scale. To overcome the crisis, it is necessary to formulate and implement a comprehensive program of innovative development of industrial sectors and mechanisms, which in turn will provide a dynamic modernization of the country as a whole.

The new policy should ensure the harmonization of the regulatory framework with international standards, the transition to the development and manufacture of multidimensional machine systems. Modular construction using the best element base that meets world standards. This requires changes in engineering education, especially in the methods of designing objects. We must go not from the achieved, but from the desired, taking into account the prospects of development.

Key words: industry, modernization, production, deindustrialization of economy, development.

Постановка проблеми. В сучасних умовах господарювання промисловість України перебуває у глибокій системній кризі. Падіння промислового виробництва у 2015 р. становило 13\%. І це - відносно показників, й так невисокого його рівня у попередні роки. Четвертий рік відбувається значний спад виробництва промислової продукції, який є наслідком не лише зниження рівня присутності вітчизняної продукції на традиційних ринках (у тому числі через зниження попиту на неї, виключення із виробничої діяльності значної частини підприємств через воєнні дії на сході країни), а й погіршення фінансово-економічних умов ix функціонування. Відповідно посилюється тенденція щодо деіндустріалізації економіки.

Сьогодні понад 90\% промислової продукції, що виробляється в Україні знаходиться на досить низькому технологічному рівні. Кількість промислових підприємств, що займались інноваційною діяльністю, $\epsilon$ вкрай малою (10-12\%). При цьому питома вага реалізованої інноваційної продукції не перевищувала 7\%. Всі ці показники в 5-7 разів нижчі, ніж в економічно розвинених країнах.

Аналіз основних досліджень i публікацій. Питанням розвитку промисловості займалися відомі вітчизняні вчені: Воловельська I.В., Дикань В.Л., Зверяков М.I, Зубенко В.О., Каличева Н.С., Мазур В.Л. та інші [1-6]. Не дивлячись на різноманіття думок, слід зазначити, що розвиток промисловості України $\epsilon$ важливим та ефективним фактором для виходу на новий, високотехнологічний рівень розвитку, а особливо в сучасних умовах, коли відбувається скорочення обсягів виробництва.

Мета статті полягає в дослідженні аналізі особливостей розвитку 
промисловості України в сучасних умовах господарювання.

Виклад основного матеріалу. Промисловий комплекс України найважливіший системоутворюючий чинник національної економіки, який значною мірою визначає рівень розвитку кожної іiі галузі. На його підприємствах працює понад 3 млн працівників. Промислове виробництво дає майже третину загальної доданої вартості, та близько половини експортної продукції. Без перебільшення, промисловість $є$ визначальним фактором реалізації життєвих інтересів країни, пї економічної безпеки, соціальних і культурних умов життя народу.

\section{Світова}

промисловість знаходиться в стані переходу на новий, високотехнологічний рівень розвитку. Сировинні ринки увійшли в одну 3 найбільших криз за період від промислової револючіï XIX століття - $i$ провідні аналітичні иентри світу схиляються до того, щзо з иієї кризи вже не буде виходу.

До моменту здобуття незалежності Україна мала розвинену, за мірками кінця $\mathrm{XX}$ ст. промисловість - від видобутку корисних копалин i виробництва 3 них сировини до високотехнологічних галузей, таких, як космічна, авіаційна, машинобудівна. Якщо говорити про масштаби, вони були відносно скромними: за підсумками 1991 p. питома вага України у світовому виробництві промислової продукції становила 0,57\%, але країна, безумовно, належала до промислово розвинених. 3 тих пір спостерігається спадна динаміка, прискорена останні кілька років: у 2013 р. частка України у світовому виробництві промислових товарів становила $0,2 \%$, в 2016 р. - 0,16\%. Падає і питома вага української економіки в світі: в 1991 р. $0,36 \%$, в 2013 р. - 0,17\%, у 2016 p. $0,12 \%$ [7].

Національна інноваційна система виявилася неспроможною стимулювати інноваційні процеси в промисловості та суттєво

впливати

на

ii

конкурентоспроможність.

Через стагнацію інвестпроцесів

відновлення виробництва не

супроводжується якісними змінами.

Промисловість демонструє переважно екстенсивний тип розвитку без змін у базових технологіях. Для виходу на новий рівень потрібні значні інвестиції, але інвестиції в основний капітал скорочуються. Головним джерелом фінансування промислових підприємств залишаються їхні власні кошти, обсяги яких також постійно зменшуються. Частка кредитних ресурсів для інвестицій не перевищує $15 \%$.

Лідерами світової економіки є Німеччина та Японія, в меншій мірі являються США і Велика Британія, і найбільш динамічні в плані розвитку економіки країни є Китай, Індія, Тайвань. Ці країни надають ключове значення розвитку національної промисловості. Це має бути прикладом для України.

Варто сконцентрувати зусилля для повернення України до числа індустріально розвинених країн. Зокрема, Україна могла б розвивати такі сфери, як викруткове складання i промисловий аутсорсинг, авіаційне і ракетно-космічне машинобудування, військовопромисловий комплекс, транспортне машинобудування, виробництво медичного обладнання, верстатобудування, сільськогосподарське машинобудування.

Якість і масштаб економіки держави в сучасних умовах визначаються не розміром ВВП або експорту, а обсягом доданої вартості, створеної у промисловості, а також місцем країни у глобальних ланцюгах доданої вартості. Українській промисловості необхідно включатися в ці ланцюжки, але робити це не 3 сировиною (тут ми вбудовані в ланцюжки доданої вартості, але перебуваємо в їх самій низько маржинальній точці), а з продукцією, в 
якій є серйозна частка доданої вартості, створена українськими підприємствами.

Після падіння обсягів

промислового виробництва в Україні протягом 2012-2015 pp., за підсумками 2016 р. у промисловості було зафіксовано зростання на рівні 2,8 \%. Проте позитивна динаміка виявилася нестійкою, і у 2017 р. виробництво промислової продукції скоротилося на $0,7 \%$. На роботі промисловості позначилося призупинення переміщення вантажів між підконтрольними та непідконтрольними територіями Донбасу та «націоналізація» бойовиками низки підприємств [8].

Як насідок, падіння виробництва відбулося, насамперед, за рахунок галузей гірничо-металургійного комплексу - у 2017 р. порівняно 32016 р. добування вугілля скоротилося на 13,6 \%, виробництво коксу та коксопродуктів - на 22,0 \%, продукції металургійної галузі на $3,0 \%$. У переробній промисловості інші галузі демонстрували переважно позитивну динаміку. Виробництво машинобудівної продукції у 2017 р. зросло на 7,7 \% порівняно з відповідним періодом 2016 р., насамперед, за рахунок виробництва оптичної та електронної продукції, а також залізничних локомотивів та рухомого складу. Високі темпи зростання у цих видах діяльності відображали виконання військових замовлень та стійкий попит на оновлення та модернізацію рухомого складу з боку ПАТ «Укрзалізниця» [8].

Збільшення обсягів виробництва у хімічній галузі відбувається повільними темпами - воно становило $1,4 \%$, що пояснюється згортанням виробництва азотних добрив у зв'язку з зупиненням декількох заводів провідних виробників. Виробництво основних фармацевтичних продуктів і фармацевтичних препаратів в умовах стійкого внутрішнього попиту на вітчизняну продукцію галузі з огляду на її вищу цінову конкурентоспроможність порівняно 3 імпортованою зросло на 1,2 $\%$. Внутрішній попит став чинником нарощування виробництва гумових, пластмасових виробів та неметалевої продукції (на 7,2 \%), зокрема, 3 боку найважливіших галузей-споживачів цієї продукції: будівництва, транспорту, АПК, медицини та ін. В інших орієнтованих на внутрішній ринок галузях також відбувалося зростання, яке склало у харчовій промисловості 4,6 \%, легкій $7,3 \%$, деревообробній - 3,5 \%, меблевій $23,2 \%[8]$.

Локомотивом української економіки в 2017 році залишилися залізорудна та металургійна галузі, незважаючи на економічну блокаду Донбасу. Через це металурги України втратили потужності Алчевського, Єнакієвського, Макеєвського та Донецького металургійних заводів. Напередодні блокади, у 2016 році, зазначені підприємства показали не лише зростання виробництва, але й сотні мільйонів гривень прибутків, які надійшли до бюджету України.

Та вже у 2017 році порівняно з 2016 p. загальне виробництво сталі в Україні зменшилося на $12 \%$ - до 21,3 млн тонн; виплавка чавуну на 5\% - до 20 млн тонн; виробництво загального металопрокату скоротилося на $14 \%$ - до 18,4 млн тонн. У світовому рейтингу виробників сталі Україна опустилася аж на 12 місце, хоча останні 20 років впевнено займала сходинку в першій десятці.

Проте, власникам металургійних підприємств вдалося знайти додаткові ринки збуту, адже валютна виручка від експорту чорних металів 2017 року проти 2016 р. зросла на $20 \%$ - до \$8,67 млрд; металовиробів - на $30 \%$, до $\$ 897$ млн. Разом вони склали 20,1\% від загального експорту країни. Втім, у металургів залишилася багаторічна проблема нестача залізничних вагонів для перевезення руди та металопрокату [9].

Не зважаючи на багато проблем в діяльності промисловості України, візитною карткою України на світовій арені може стати космічна галузь. Досі 
вона не отримувала належної підтримки від держави, тож мусила сама собі допомагати.

Головний виробник космічних ракет - завод «Південмаш» уже в 2017 р. відновив виробництво ракет-носіїв «Зеніт» для міжнародних проектів Sea Launch («Морський старт») и Land Launch («Наземний старт»). Поки що йдеться про 12 ракет, проте, може бути прийняте рішення щодо збільшення кількості пусків [9].

Крім того, у 2018 році очікується розширення промислової кооперації із компанією Orbital ATK Inc. (США) за програмою будівництва ракети-носія середнього класу Antares. Ракети забезпечують виконання контракту NASA iз постачання матеріалів, обладнання та продуктів на міжнародну космічну станцію (МКС). «Південмаш» розраховує, що американські контрагенти замовлять додаткові конструкції для першої ступені на ракети Antares. А це принаймні ще 12 конструкцій [9].

Дієвий інноваційний процес запропонував харківський ПАТ «Завод Фрунзе» - виробництво системи огорожі, обладнані сонячними панелями. Вони можуть використовуватися як самостійно, так і додатковими опорами для сонячних електростанцій на дахах будинків. Ідея полягає в тому, що огорожа може стати джерелом додаткового доходу. В багатьох випадках, коли споживач відчуває дефіцит вільних площ, це буде оптимальним рішенням.

Також рішення дозволяє зробити повністю автономні огорожі, які самі себе забезпечать електроенергією для підсвічування та відеоспостереження. Це, зокрема, дозволить підвищити якість життя мешканцям погано електрифікованих населених пунктів.

Дослідивши діяльність промисловості України за останні роки можна сказати, що Уряд країни поки що не в змозі провести хоч якісь реформи в промисловості, проте намагається запустити окремі підприємства, які до цього роками не працювали. Одним 3 таких стало ТОВ «Карпатнафтохім» у місті Калуш Івано-Франківської області, яке простоювало з 2012 року. Наприкінці 2016 року держава скасувала акциз на імпорт скрапленого газу та дизпалива для виробництва етилену. $\mathrm{y}$ червні «Карпатнафтохім» запустився. Потужність підприємства складає $250 \quad 000$ тонн етилену на рік. 3 цієї сировини виробляються поліетилен та полівінхлорид, які йдуть на експорт.

На прибуткову роботу вийшов $\mathrm{i}$ Запорізький алюмінієвий комбінат - ЗалК - єдиний виробник первинного алюмінію в Україні. У 2015 році завод повернули у власність України після того, як ним володіла російська компанія «РУСАЛ». За перше півріччя 2017 року ЗАлК отримав 227 млн грн прибутку. На жаль, комбінат й досі не завантажений на повну потужність, бо йому не вистачає сировини.

Проблеми промисловості мають загальнонаціональний масштаб. Виникла загроза технологічній безпеці країни, що потребує розробки системи заходів, спрямованих на переведення промислового комплексу у стан, який відповідає потребам розвитку країни. Якісно новий стан і рівень промисловості може забезпечити лише нова інноваційна стратегія її розвитку.

Майбутнє українських підприємств із галузей напівсировинного виробничого сегмента (застарілих металургії, хімічної промисловості, примітивного машинобудування) представляється малоперспективним. У цих галузях у світі існує такий надлишок виробничих потужностей, причому набагато більш продуктивних i ефективних, ніж українські, що навряд чи наші підприємства зможуть завоювати більшу частку ринку, ніж та, яка $є$ у них зараз. Погіршує ситуацію непродуктивність i неефективність внаслідок високої зношеності основних фондів. 
На погляд авторів, існує вихід із кризи - мобілізація зусиль влади, вчених, конструкторів, працівників промисловості, бізнесу, громадських організацій на формування i реалізацію комплексної програми інноваційного розвитку промислових галузей i механізмів, що забезпечать динамічну модернізацію країни.

Наслідками формування нової промислової політики мають стати визначені характеристики промисловості, iii виробнича i продуктова структура й параметри. Це потребує створення організаційно-правового механізму узгодження інтересів і відповідальності держави, бізнесу та представників громадянського суспільства на довгостроковій основі. Необхідно формувати у бізнесі організаційну культуру до постійної взаємодії з наукою щодо створення нових інноваційних технологічних рішень, використовувати для цього великий потенціал існуючих промислово-фінансових об'єднань. Актуальним завданням є трансформація існуючих кланово-олігархічних монополій у систему промислово-фінансових структур, що інтегрують у собі реалізацію не тільки корпоративної, а й державної політики.

Інституціональна

структура промисловості повинна стати сучасною, перетворившись із фрагментарного на цілісний, інтегрований у світове виробництво комплекс, що здатний до високорентабельної діяльності та саморозвитку, поєднує збалансовані потребами зовнішнього i внутрішнього ринків системно структуровані галузеві утворення, відповідає вимогам екології й енергозбереження.

Нова структура комплексу повинна бути триланковою відповідно до конкретних умов, включати вертикально і горизонтально інтегровані структури. Наступною має стати ланка інтегральних утворень - корпорацій, об'єднань, холдингів, концернів. Особливу увагу треба

приділити

формуванню горизонтальних інтегральних об'єднань кластерів, здатних об'єднати можливості підприємств, у тому числі малих i середніх, при реалізації проектів і програм як на регіональному, міжрегіональному, так і на галузевому рівні. Важливим завданням виступає створення фонду розвитку промисловості. Формування інтегрованих структур має враховувати зарубіжний досвід виконання такої роботи, що дасть змогу мінімізувати ризики іiі низьких результатів.

На думку авторів, інноваційна державна промислова політика повинна базуватися на стратегічному та галузевих довгострокових прогнозах й інтегрувати найкращий світовий досвід. Важливо сформувати вдосконалену систему наукового та освітнього забезпечення розвитку промисловості. Необхідно відродити ланку галузевої науки, що сьогодні майже ліквідована.

Також слід створити національний науковий центр розвитку промисловості та систему його філіалів по комплексу галузей, на які покласти завдання розробки стратегічних i технологічних прогнозів, координації виконання стратегічно важливих проектів, інтеграції розробок інститутів НАНУ і галузевих інститутів, вищих навчальних закладів та інших суб'єктів науково-інноваційної діяльності. Треба забезпечити виконання Закону України «Про наукову і науково-технічну діяльність» [10] у частині фінансування вітчизняної науки на рівні 1,7\% ВВП.

Нова технічна політика повинна забезпечити гармонізацію нормативної бази 3 міжнародними стандартами, перехід на розробку i виготовлення багатовимірних систем машин. Модульна побудова 3 використанням найкращої елементної бази, що відповідає світовим стандартам. Для цього необхідні зміни в інженерній освіті, особливо у методах проектування об'єктів. Треба йти не від досягнутого, а від потрібного 3 урахуванням перспектив розвитку. 
В сучасних умовах традиційні показники оцінки матеріального виробництва - індекси поточної конкурентоспроможності - перестають відображати якісний бік економічної динаміки, а просте господарське зростання вже не може забезпечити його стабільність i комплексний розвиток. Вважаємо, що більш ефективним, стимулюючим до динамічного інноваційного розвитку міг би бути індекс перспективної конкурентоспроможності, який визначається рівнем новизни та наукоємності продукції та включає показники зростання доданої вартості, рентабельності i структури активів, матеріало- та енергоефективності, що сприятиме переходу до стратегії інноваційного розвитку.

Висновки. 3 наведеного вище можна зробити наступні висновки, що до моменту здобуття незалежності Україна мала досить розвинену промисловість. За останні роки промисловість України має негативну тенденцію, зменшення виробництва так: у 2013 р. частка України у світовому виробництві промислових товарів становила $0,2 \%$, в 2016 р. $0,16 \%$.

Рушійною силою для розвитку діяльності промисловості України на світовій арені може стати космічна галузь. Досі вона не отримувала належної підтримки від держави, тож мусила сама собі допомагати.

В статті, автор пропонує створити національний науковий центр розвитку промисловості та систему його філіалів по комплексу галузей, на які покласти завдання розробки стратегічних i технологічних прогнозів, координації виконання стратегічно важливих проектів, інтеграції розробок інститутів НАНУ i галузевих інститутів, вищих навчальних закладів та інших суб'єктів науковоінноваційної діяльності.

Національний науковий центр розвитку промисловості повинен забезпечити гармонізацію нормативної бази
3 міжнародними стандартами, перехід на розробку i виготовлення багатовимірних систем машин. Для цього необхідні зміни в інженерній освіті, особливо у методах проектування об'єктів. Треба йти не від досягнутого, а від потрібного 3 урахуванням перспектив розвитку.

\section{СПИСОК ВИКОРИСТАНИХ ДЖЕРЕЛ}

1. Воловельська

I.B.

Экономическая

безопасность промышленного предприятия в современных условиях / І.В. Воловельська // Вісник економіки транспорту i промисловості. - 2005. - №9 - С.25-27.

2. Дикань В.Л. Роль государства в создании условий возрождения промышленного потенциала Украины / В.Л. Дикань // Вісник економіки транспорту i промисловості. Збір наук. праць - Харків, УкрДАЗТ, 2012 № 40. C. $13-17$

3. Зверяков М.И Промышленная политика и механизм ее реализации /М.И. Зверяков // Экономика Украины: - Киев, 2016. -№6. - С.3-18.

4. Зубенко В.О. Зміна парадигми забезпечення конкурентоспроможності промислових підприємств України / В.О. Зубенко // Вісник економіки транспорту i промисловості. - 2012. - №40. - С.160-162.

5. Каличева Н.С. Напрями забезпечення ефективного розвитку промислових підприємств в сучасних умовах / Н.С Каличева, С.Є. Бохан // Науковий огляд. Науковий журнал. - Київ, ТОВ «Меганом», 2017. - Вип. 5 (37). -С. 5 15

6. Мазур В.Л. Проблемы промышленной политики в Украине /В.Л. Мазур// Экономика Украины: - Киев, 2016. - №11. - C.3-18.

7. Про відновлення промисловості часів УРСР треба забути [Електронний pecypc]. - Режим доступу: https://dt.ua/ECONOMICS/providnovlennya-promislovosti-chasiv-ursrtreba-zabuti-ekspert-262041_.html 
8. Щодо пріоритетних напрямів здійснення реформ у промисловості України, аналітична записка [Електронний ресурс]. - Режим доступу: http://www.niss.gov.ua/articles/2762/

9. Підсумки-2017: українська промисловість [Електронний ресурс]. Режим доступу: https://mind.ua/publications/20180265pidsumki-2017-ukrayinska-promislovist 10. Закон України «Про наукову i науково-технічну діяльність» [Електронний ресурс]. - Режим доступу: http://zakon2.rada.gov.ua/laws/show/848-19

DOI 10.18664/338.47:338.45.v\%vi\%i.133529
11. Дикань В.Л. Глобализационные процессы в экономике Украины / В.Л. Дикань, А.В. Кузуб // Вісник економіки транспорту i промисловості. збірник наукових праць. - Харків, УкрДУЗТ, 2017. №58. C.9-18

12. Данько M. I. Підвищення інвестиційно-інноваційного потенціалу промислових підприємств залізничного транспорту в умовах інтеграційних процесів: монографія/ Данько М.І., Дикань В.Л., Калініченко Л.Л.-Харків: УкрДАЗТ.2010.-167 с. 